\title{
Assessment of agricultural practices for improving quality of cocoa beans: South-West Cameroon
}

\author{
Edgar Wakam Ouokam ${ }^{1}$; Yan Yunxian ${ }^{1 *}$; Mgale Yohana James ${ }^{1}$, Michael Osei \\ Appiah $^{2}$, Gaboinewe Motlehewa ${ }^{1}$
}

\author{
${ }^{1}$ College of Economics and Management, Jilin Agricultural University, Changchun, China \\ ${ }^{2}$ College of Animal Science and Technology, Jilin Agricultural University, Changchun, China
}

\begin{abstract}
Purpose: Cocoa is the main cash crop in Cameroon, with about $30 \%$ of Gross Domestic Product of agricultural produce for export and processing. Many studies depict that, despite the efforts of Cameroonian producers, the quality of their production still needs improvement. This research work was carried out in the MEME district south-west region of Cameroon, with the aim to assess the different agricultural practices used by producers to improve the quality of their cocoa beans.
\end{abstract}

Research method: Seventy-eight cocoa farmers were chosen in that district and interviewed using structured questionnaires and personal observations if possible.

Findings: Our survey shows that the difficulties farmers face in providing better cocoa beans quality reside in the financial credits; diseases and pests; the cost of inputs including spraying cost and lack of access to energy. These constituted $83.89 \%$ of the difficulties related to the quality of cocoa beans in that area. Also, our findings depicted that to ensure the quality of cocoa beans, most farmers apply normal spraying, proper fermentation and proper drying.

Research limitation: The lack of technical know-how in good agricultural management practices, lack of input subsidies, credit facilities and insufficient electricity grid are the obstacles that reduce the quality of cocoa beans.

Original value: We recommend that cocoa mass spraying be extended to all farmers, to prevent pests and diseases effects; In addition, facilitate access to credit and increase the electricity grid; which will enable easy access to new technologies to dry cocoa beans.

Keywords- Cameroon; Cocoa beans; Quality; Agricultural Practices.

\section{INTRODUCTION}

Agriculture is the main source of growth and foreign exchange in Cameroon (here in after known as CMR), the contribution of agriculture to the economic growth of
Cameroon is about $76.38 \%$ (CMR, 2019). In 2015, agriculture accounted for $22.3 \%$ of GDP of the economy of Cameroon. According to the World Record in an article published in June 2013, agriculture was the main occupation for nearly $60 \%$ of the active population. In Cameroon, agriculture is rich and varied and cocoa is one of the main cash crops amongst coffee, rubber, banana, cotton, tea etc. According to government statistics, cocoa beans accounts for about half the country's exports earnings, with an average annual production up than 300000 tons (Business in Cameroon, 2018). Cocoa beans sales contribute about 250 billion CFA francs ( $\$ 426$ million). The cocoa sector accounts for about $2 \%$ of the national GDP and $6 \%$ of the primary GDP and about $30 \%$ of the GDP for the export and processing of agricultural products (Pierre E.A, 2006). The cocoa sector is largely dominated by exporters of unfinished products, namely raw cocoa beans. However, producers are still struggling on how to improve its quality. The cocoa sector has drawn the attention of government over the past two decades to increase production levels, quality and foreign exchange earnings. Achieving these objectives has called for measures to maintain and improve the quality of cocoa beans which is directly related to cocoa beans value (KWESSEU P.J.M, 2008. The national goal is to produce 600,000 tons of cocoa by the year 2020 (Yasmine B.D, 2018). A significant harvest of more than two hundred thousand tons (200 000t): 382, 000t in the 2016/2017 season (Yasmine B.D, 2018) suggests that the country is likely to meet or exceed its target. Among the reasons for the good performance of Cameroon's cocoa sector over the last decade are, the prudential policy reforms of the cocoa sector, including strategic reforms, various incentives, strengthening of producer supervision; furthermore, efforts to improve the quality of cocoa beans are equally important, for example, there is strong government involvement in export marketing and quality 
control through Licenses Buying Companies (LBCs) (IRAM. 2012), the construction of equipment to better treat the cocoa beans; rigorous quality controls at village-level buying centers; and pick-up points for the onward shipment of cocoa beans for export and processing. All these through strict recommendations to LBCs by the government for them to pay more attention in order not to adulterate cocoa beans sold to the cocoa board for shipping.

When perceived for its quality, it appears that the quality of cocoa beans has endured a shot/hit since the progression of the segment in 1991 (Pierre E.A, 2006). As per the United Nations Conference on Trade and Development (UNCTAD), market progression has made new challenges, including controlling general production and keeping up the nature of production in an aggressive market condition. They remarked that the debasement of yield quality was one of the primary difficulties of the progression of export harvests, for instance, cocoa bean. Numerous specialists have upheld this theory by showing that the advancement of this sector has highlighted and quickened the debasement of the cocoa beans quality, because of competition from purchasers to combine or enlarge their piece of the overall industry; it was additionally discovered that the pressure applied by LBCs in Cameroon to acquire cocoa from farmers was behind the clearance of high-moisture cocoa beans. This has favored the improvement of shape, a standout amongst the most significant quality deformities of cocoa beans and for which purchasers will limit intensely in the global market. For example, in 2013, 1,300 kg of lowquality cocoa beans were bend in the area of Bafia in Cameroon.

Market-decided premiums in product markets are based, in addition to other things, on view of value. It was noticed that, in perspective on the global prerequisites for the quality of cocoa beans, Cameroon still needs to attempt to improve the quality of its cocoa beans, as market requests keep on developing (CMR, 2019). The purchaser, the cocoa processor and the chocolate maker must be happy with the quality of the products conveyed on the worldwide market. A low-quality cocoa bean can prompt attribution cases, los s of share of the overall industry and salary, and stain the notoriety of Cameroon's cocoa beans. Basic quality issues in the cocoa and related items include incorporate form, slate, fat substance, dampness content, taste, presence of foreign material, and different imperfections in cocoa beans (Nlend A.L et al., 2017). Quality is assessed dependent on flavor, smell, consistency, yield, bean estimate, hull percentage and fat substance, all these influence the decision of cocoa beans. (Barel, M. 2013). The physical attributes of cocoa beans and the flavor of cocoa beans are unequivocal factors in the quality of these cocoa beans.

Cameroon can build the quality of its export cocoa beans by setting up and spreading great agricultural practices and by giving sponsorships to farmers. Cocoa farmers in Cameroon apply practices that don't generally ensure the quality of cocoa beans, a label that to be pleased with. To plan cocoa beans available to be purchased, the farmer must be mindful so as to deal with great and bad seeds of the cocoa beans, regularly discarding the greater part of the bad ones. The production of value cocoa beans relies upon a few components and it has been contended that $80 \%$ of the quality of cocoa beans relies upon the proper cultivation, drying and fermentation techniques embraced by farmers (C. Amani, 2014). Issues that obstruct the accomplishment of international quality measures for cocoa beans are commonly arranged into natural and structural / financial factors components. Characteristic elements incorporate the impacts of climate, daylight and drying of cocoa beans while, structural / financial components include: absence of direct extension services; subsidizing of research activities; elevated amounts of chemical residues; presence of heavy material; utilization of jute sacks for the export of cocoa beans; and delivering technique. The underlying driver of anomalies in cocoa beans could be credited to poor agricultural practices, pest and disease invasion, mishandling, poor fermentation, deficient drying, high moisture that makes the product defenseless against form and bacterial development. Different reasons for low quality of cocoa beans are poor and long timeframe bringing about fat debasement and nuisance invasion in the absenceof fumigation and different measures in order to maintain quality (Nlend A.L et al., 2017). As supported by the government (CMR, 2019), the principal challenge to keep up the certainty of cocoa bean purchasers in Cameroon, is to guarantee consistency and quality improvement of the cocoa beans given by the nation. As indicated by the Government, "this infers that, cocoa farmers must proceed not exclusively to follow and receive great agronomic practices, yet in addition to improve the great agricultural practices they presently apply" (CMR, 2019).

The goal of this survey article is to look at agricultural practices that will assist farmers with ensuring great quality of their cocoa beans, relieve difficulties farmers face in keeping up cocoa bean quality, and furthermore assess measures to improve the quality of cocoa beans in the MEME region of Cameroon. Moreover, this investigation 
will likewise assist us with diagnosing and feature the shortcomings of value confirmation measures in the Cameroonian cocoa division, so the nation can keep on improving its quality status on the international market.

\section{MATERIALS AND METHODS}

\section{Sample area of the survey study}

MEME district is in the south-west region of Cameroon, which is the country's largest producing area with a $45.45 \%$ (table4) share of production at the national level (CMR, 2019). The region is in the forest zone and the principal occupation of the occupants is farming, exchange/business and little scale mining. The climate of the region is characterized by average annual rainfall of about $3000 \mathrm{~mm}$ and a long rainy season from March to November, attenuated by a small dry season (in June), and interrupted by a long dry season of 3 months (December to February). Two forest formations predominate in South-West Cameroon; (1) the Biafrane evergreen forest which is very diversified, has a high abundance of Caesalpiniaceae, (2) the Atlantic littoral forest, which is poor in Caesalpiniaceae and characterized by the abundance of Loflhiraalata (Ochnaceae), Sacogottisgabonensis (Humiriaceae), Coula edulis (Olacaceae) and Cynometrahankei (Caesalpiniaceae). Furthermore, Lake Ossa, in areas not degraded by the development of food crops, the Atlantic coastal forest dominates (Isabelle et al., 1996). The district is suitable for cocoa production, therefore, three communities in that district were purposively selected for data collection. These communities are part of the main cocoa producing communities in the district. Seventy-eight cocoa producers were randomly selected from them, namely KUMBA I, KUMBA II and KUMBA III (Fig.1). The total population of MEME is about 384, 286 people (FOLEFACK D.P, 2003) which account for about $7.1 \%$ of the national population; the land area of MEME is $3105 \mathrm{~km}^{2}$ (CMR, 2019). About 26 farmers from each community were approached and interviewed using well-structured questionnaires and personal observations where possible. The information was coded and analyzed down utilizing the Statistical Package for the Social Sciences (SPSS, 2007) version 16. The results were displayed in tables, figures, rates.

\section{RESULTS AND DISCUSSION} Producers' Socio-Economic Characteristics:

The results of the respondents revealed that $97.43 \%$ were men and $2.56 \%$ were ladies (fig 2). Likewise, as indicated by the results acquired from the study, $37.17 \%$ of the respondents were aged between 55 to 75 years of age, $48.71 \%$ were aged between 35 to 54 years of age, and $14.10 \%$ were aged somewhere in the range of 18 and 34 years of age (fig 3). The age structure demonstrates that most farmers are moderately old. Additionally, cocoa development in the examination zone was for the most part done by generally older male farmers. Cocoa cultivating is a dreary activity that requires a great deal of strength [ASEAN Free Trade Area (AFTA), 2005]; the generally propelled time of cocoa producers can influence their productivity and basic decision making. Men's dominance in cocoa production may likewise be clarified by the way that, men generally claim land and have simpler access to land in most rural communities. About $16.53 \%$ of farmers had casual training; near $57.69 \%$ has essential/middle school education, $21.45 \%$ has secondary school education and $4.33 \%$ had tertiary education (fig 4). The level of education of the respondents was accordingly low, which could influence their speedy adoption of agricultural technologies. Almost $89.74 \%$ of farmers have been growing cocoa for around 20 years, while $10.26 \%$ have been growing it for around 10 years (fig 5). This delineated that most respondents have impressive involvement in cocoa production. We likewise discovered that about $95 \%$ of the respondents were experienced cocoa farmers with over 10 years of involvement in cocoa production (fig 5). The generally long periods of cultivating are probably going to improve their insight into cocoa production; pre and postharvest agricultural practices.

\section{Issues encountered by farmers in ensuring quality of} cocoa beans :

As indicated by the survey study, the fundamental is sues influencing the nature of cocoa beans in that region were absence of access to credit, pest and disease invasion, surprising high expense of inputs (spraying, fertilizer and so forth.) and energy (Table 1). These represented $84.6 \%$ of the issues influencing the nature/quality of cocoa beans (Table 1).

As indicated by farmers, they face financial difficulties in actualizing the prescribed practices to guarantee high quality of their cocoa beans and they credited this to the high expense of agrochemicals and spraying machines to protect their farms against pest and disease (Table 1). As indicated by Denis et al., (2002), the rate of pest and disease invasions of cocoa in Cameroon (south-west) endured and added to the weakness of quality yields. The presence of pest, for example, Tapinanthusglobiferus compete with the 
cocoa tree for water and supplements, which diminishes yield, while diseases, for instance, black pod additionally cause deformity of the cocoa pods, bringing about a decrease in the size of the beans. As revealed by (Assonwa F.E, 2015), most farmers did not control pests and diseases, due to the high cost of pesticides, spraying equipment and labor. Respondents showed that not all farmers profited from the government mass cocoa spraying exercise, and the individuals who needed to spray their own cocoa farms found the cost exorbitant. Farmers anyway noticed that when farms are appropriately sprayed, pods are sheltered from disease, bringing about quality beans. (Kokou E, 2014) revealed that government spraying efforts to spray cocoa farms have been called attention to by respondents as not covering the majority of the producer farms and furthermore not being continuous. They likewise guarantee that the spraying of cocoa farms to control pests and diseases has not achieved its maximum capacity as it has not had the option to satisfy its order to guarantee that cocoa farms are sprayed two times every year. Then again, the increasing expense of work represents a test to the capacity of farmers to keep their farms free of weeds, in this way trading off the quality of the cocoa beans produced. Moreover, the is sue of energy thwarted the entrance to new advances in drying cocoa beans; along these lines, influencing the quality, since the drying phase in cocoa beans is significant (Denis et al., 2002).

\section{Producers' Practices to Ensure the Quality of Cocoa Beans}

Producers sell their cocoa beans legitimately to license buying companies (LBCs) which decide the quality of cocoa beans preceding buy. They arbitrarily select a portion of the cocoa beans that they have split-up to decide the brownness of the cocoa beans, a certification of value. According to the United States Department for Agriculture (USDA), 2005, poor quality cocoa beans have a purple coloration, heterogeneous bean size, displaced taste and aroma, sick beans, moisture and the presence of foreign materials. These problems result from irregular rainfall, pests and diseases, improper fermentation and poor drying of cocoa beans. Moisture, for example, results from inadequate and / or incomplete drying.

From Table 2, it has been found that the primary strategies utilized by cocoa producers to ensure astounding cocoa beans are normal spraying, appropriate fermentation and legitimate drying. These practices represented about $58 \%$ of farmers' reaction to measures taken to guarantee high quality of cocoa beans. As confirmed by C. Amani (2014), low quality cocoa beans are the after effect of unpredictable rainfall, pest and diseases, inappropriate fermentation and poor drying of cocoa beans. Likewise, ordinary and satisfactory farms upkeep results in uniform measured cocoa beans while normal weeding control prevents weeds that harbor pests and diseases. Farmers likewise permit the pods to ripen appropriately before gather as they need to ensure the quality of their cocoa beans. Likewise, the breaking of the pods is completed following reaping to dodge the loss of quality of the product. Pruning, application of fertilizers, prevention action of over-torn seeds and choice of ailing seeds are different practices received by farmers to guarantee their cocoa bean quality. National Cocoa and Coffee Board (NCCB), 1991, based on international recommendations, has distinguished the cocoa quality control measures to be embraced by cocoa farmers in Cameroon, including appropriate mamagement practices, convenient harvesting, and appropriate fermentation, legitimate drying and good storage of the dried cocoa beans.

\section{Producers' proposals on measures to guarantee high quality of cocoa beans}

As portrayed in Table 3, it can be seen that, $57.69 \%$ of farmers proposed loaning to farmers through microfinance plans to enable farmers to purchase the necessary inputs, for instance, spraying guns as this will enable them to spray their farms two times per year as prescribed to guarantee great control of pests and diseases. Twenty-five-point sixty four percent $(25.64 \%)$ of cocoa producers have likewise recommended subsidies on inputs, particularly spraying guns (Table 1) in order to decrease the expense of renting guns and guaranteeing regular farm spraying. Eleven-point fifty three percent (11.53\%) of respondents likewise proposed post-harvest management expansion preparing to empower farmers to deliver high quality of cocoa beans (Table 1) and $5.12 \%$ respondents also mentioned the creation of farmers' cooperatives as a means of training in extension and information dissemination (Table 1).

\section{CONCLUSION AND RECOMMENDATIONS}

Getting great quality cocoa beans requires joint effort between various on-screen characters in the cocoa business, to be specific farmers, authorized purchasing organizations, quality government establishments (CICC/NCCB), extension service providers, cocoa processors and worldwide purchasers. However, farmers play an urgent and focal job in guaranteeing the quality of cocoa beans through 
their management practices and the treatment of cocoa beans pre and post-harvest. Cocoa farmers in Cameroon are quality cognizant and attempt incredible endeavors to guarantee better quality of their cocoa beans. There are, however, a few reasons against the insurance of the quality of cocoa beans, yet these difficulties have not prevented farmers from attempting to improve the quality of their cocoa beans. The liberalization of the internal marketing of cocoa has led to a reduction in the quality of cocoa beans in Cameroon. Farmers' capacity to keep up quality in a changed framework infers that they fuse certain production costs, which will eventually diminish the makers' gains of cocoa farmers from cocoa production. It is very prescribed that all on-screen characters in the cocoa business in Cameroon keep on working eagerly to keep up and improve the quality of cocoa beans with the goal that the nation can trade high grade of cocoa beans to keep up its notoriety in the global market and to guarantee a better status. In addition, it is suggested that farmers be given credit facilities to control pests and diseases to protect thequality of cocoa beans. Building up a component for farmers to acquire credit so as to rapidly adjust their management practices will improve the quality of cocoa beans. Also, the cocoa mass spraying activity ought to be appropriately checked to guarantee that all farms have access under the suggested routine. At long last, the expansion of the electricity grid should be extended to cocoa growing communities, so as to allow producers to have access to new drying systems, thus insuring better quality of cocoa beans.

\section{REFERENCES}

[1] AFTA, 2005.Human Rights (Feedar\&Hr), Cameroon, Conference Proceedings.

[2] Amani, C. 2014. Get quality beans.

[3] ASSONWA, F, E. 2015. Assessment of pests and diseases management on cocoa production: case study of EKONDO-TITI NDIAN division Cameroon.

[4] Barel, M. 2013. Cocoa quality - the impact of postharvest processing. Article

[5] CMR, 2019. Business in Cameroon, (https://www.investiraucameroun.com/agriculture/220 8-11237-la-contribution-de-l-agriculture-a-lacrois s ance-economique-du-cameroun-a-ete-de-76-38en-2017) accessed on January 2019

[6] CMR, 2019.

Economy,(https://leconomie.cm/cameroun-253-510- tonnes-de-feves-de-cacao-commercialisees-en-2016-

2017/) accessed on January 2019

[7] CMR,2019(https://www.google.com/search?biw $=128$ o\&bih=631\&ei=rk9PXJTOIc_DigTy6Y4o\&q=Meme + Cameroun + superficie \& oq $=$ Meme + Cameroun + supe rficie\&gs $l=$ psyab.3..33i160l2.23669.30850..31181... 0.0..0.1296.4703.5-3j2j1.....0...1..gwswiz.......0i71j0i22i30.HJKgMlbzA_o ） Accessed on December 2018

[8] Denis J. Sonwa, 1 Ousmane Coulibaly, 3 Akinwumi Adesina, 4 Stephan F. Weise, and Mathurin Chatat. 2002. Integrated pest management in cocoa agroforests in southern Cameroon: Constraints and overview. 191-199

[9] FOLEFACK Denis Pompidou. 2003. Socio-economic analysis of cocoa marketing in the forest zone of southern Cameroon. Thesis.

[10] Human Rights (Feedar\&Hr), Cameroon. AFTA 2005 Conference Proceedings

[11]INS. 2016. Cameroon - Third Cameroonian Household Survey 2007. 13982p

[12] IRAM. 2012. Study on the marketing potential of Cameroon's cocoa in "Geographical Indication". AGRI --- 2012 --- --- 05 EVAL

[13] Isabelle et al., 1996. Vegetation and climate in the forests of southwest Cameroon since 4 '7'10 years BP: pollen analysis of Lake Ossa sediments. 105789

[14] KokouEdohAdabe and E. Lionelle Ngo-Samnick. 2014. Production and processing of cocoa. PROAGRO Collection.

[15] KWESSEU PETGUEN Jacques Marcien, 2008. Qualitative analysis of cocoa-crop systems in the central region, Cameroon. Master Engineering.

[16] Monique B. 2012. Study on the marketing potential of Cameroon's cocoa in "Geographical Indication". AGRI --- 2012 --- --- 05 EVAL

[17]Nlend A.L et al., 2017. Institutional and Organizational Determinants of Cocoa Certification in Cameroon: Case of the UTZ Certification System in the Central Region.

[18] Pierre, E.A, 2006. The Liberalization of the Cacao / Coffee sector of Cameroon and the Transparency of the Marches

[19] SCCR. 2009. Guidelines on known best practices in the cocoa sector

[20] SPSS. Statistical Package for the Social Sciences (SPSS, 2007) version 16. 
[21] The advice of Café-Cacao. 2018-2019. Export standards for cocoa. Newspaper

[22] UNCTAD, 2006. The Liberalization of the Cacao / Coffee sector of Cameroon and the Transparency of the Marches
[23] USDA. 2005. United States Standards for Beans

[24] Yasmine B.D. 2017/2018. business in Cameroon. $68 / 69$

Table 1: Issues encountered by farmers in ensuring quality of cocoa beans:

\begin{tabular}{lcc}
\hline Problems & Response (\% score) & Rank \\
\hline Financial constraints & 42,3 & 1 \\
Pests and diseases & 23,1 & 2 \\
\hline High cost of spraying & 11,5 & 3 \\
Problem of energy & 7,7 & 4 \\
High cost of labor & 5,1 & 5 \\
Unavailability of good variety & 3,8 & 6 \\
\hline Irregular rainfall & 3,8 & 6 \\
\hline Long distance of cocoa farm & 1,3 & 7 \\
\hline Poor health of farmer & 1,3 & 7 \\
\hline
\end{tabular}

Table 2: Producers' Practices to Ensure the Quality of Cocoa Beans

\begin{tabular}{lcc}
\hline Problems & Response (\%score) & Rank \\
\hline Proper drying & 26,9 & 1 \\
Regular spraying & 16,7 & 2 \\
\hline Proper fermentation & 14,1 & 3 \\
\hline Planting good variety & 10,3 & 4 \\
\hline Quick breaking of cocoa pods & 7,7 & 5 \\
Allowed pods to mature well & 6,4 & 6 \\
Pruning & 6,4 & 6 \\
Application of fertilizer & 5,1 & 7 \\
Avoiding over-ripped pods & 3,8 & 8 \\
\hline Selection of diseased pods & 2,6 & 9 \\
\hline
\end{tabular}

Table 3: Producers' proposals on measures to guarantee high quality of cocoa beans

\begin{tabular}{lcc}
\hline Problems & Response (\% score) & Rank \\
\hline Access to credit & 57,7 & 1 \\
Subsidies & 25,6 & 2 \\
$\begin{array}{l}\text { Education on post-harvest } \\
\text { management }\end{array}$ & 11,5 & 3 \\
Formation of farmers' co-operatives & 5,1 & 4 \\
\hline
\end{tabular}




\begin{tabular}{lcl}
\hline & Table 4: Cocoa bean production 2016 in Cameroon \\
\hline Regions & Production (tons) & Percentage $(\%)$ \\
\hline South-West & 132492.204 & 45.45 \\
Centrral-region & 107859.44 & 37 \\
Littoral & 20347.53 & 6.98 \\
South & 15546.44 & 4.99 \\
East & 9853.10 & 3.38 \\
West & 4256.07 & 1.46 \\
North-west & 3760.50 & 1.29 \\
\hline
\end{tabular}

Table 5: Quantity production, harvested area, production/yields, average price to farmers

\begin{tabular}{lllll}
\hline Years & $\begin{array}{c}\text { Production quantity } \\
\text { (tons) }\end{array}$ & exported & $\begin{array}{l}\text { Production yields } \\
\text { (hg/ha) }\end{array}$ & $\begin{array}{l}\text { Average price to } \\
\text { farmers/kg in } \\
\text { XAF }\end{array}$ \\
\hline $\mathbf{2 0 0 0}$ & 120619 & & 3298 & 580 \\
$\mathbf{2 0 0 1}$ & 120877 & 371742 & 3347 & 700 \\
$\mathbf{2 0 0 2}$ & 112281 & 364753 & 3416 & 700 \\
$\mathbf{2 0 0 3}$ & 128646 & 365938 & 3444 & 500 \\
$\mathbf{2 0 0 4}$ & 126752 & 450000 & 3403 & 600 \\
$\mathbf{2 0 0 5}$ & 130490 & 490000 & 3500 & 690 \\
$\mathbf{2 0 0 6}$ & 164523 & 400000 & 3740 & 800 \\
$\mathbf{2 0 0 7}$ & 212619 & 440000 & 3866 & 939 \\
$\mathbf{2 0 0 8}$ & 229203 & 131127 & 3885 & 1152 \\
$\mathbf{2 0 0 9}$ & 230032 & 178101 & 3925 & 1491 \\
$\mathbf{2 0 1 0}$ & 244077 & 193973 & 3941 & 1695 \\
$\mathbf{2 0 1 1}$ & 246120 & 193881 & 3582 & 1356 \\
$\mathbf{2 0 1 2}$ & 250000 & 190214 & 4014 & 1095 \\
$\mathbf{2 0 1 3}$ & 268941 & 173794 & 4104 & 1358 \\
$\mathbf{2 0 1 4}$ & 232530 & 192836 & 4021 & 1500 \\
$\mathbf{2 0 1 5}$ & 269495 & 198,129 & 4012 & 1050 \\
$\mathbf{2 0 1 6}$ & 231642 & 181893 & 4027 & 1400 \\
$\mathbf{2 0 1 7}$ & 382000 & 169530 & - & \\
\hline $\mathbf{S 0 u r}$ & 170981 & &
\end{tabular}

Source: Faostat/Oncc, 2017. INS, 2015, Pierre E.A, 2006 
Table 6: Quality of cocoa from 2000/2001 to 2012/2013 ( Kg).

\begin{tabular}{|c|c|c|c|c|c|c|c|c|c|}
\hline & GI/GF & $\%$ & GII/FF & $\%$ & HS & $\%$ & NC & Residues & Total \\
\hline 2000 & 2104,618 & 2 & 103126,305 & 98,00 & 0 & & 0 & 0 & 105230,923 \\
\hline 2001 & 2624,738 & 3 & 84866,541 & 97,00 & & & & & 87491,279 \\
\hline 2002 & 1377,170 & 1,29 & 105151,276 & 98,67 & 43080 & 0,04 & & & 106571,526 \\
\hline 2003 & 1289,210 & 1,11 & 114488,589 & 98,89 & & & & & 115777,799 \\
\hline 2004 & 1756,740 & 1,41 & 123275,370 & 98,59 & & & & & 125032,110 \\
\hline 2005 & 6069,360 & 5,07 & 113409,659 & 94,72 & 250800 & 0,21 & & & 119729,819 \\
\hline 2006 & 10796,280 & 7,55 & 131853,802 & 92,26 & 234240 & 0,16 & 25080 & & 142909,402 \\
\hline 2007 & 1805,760 & 1,11 & 160004,220 & 97,94 & 1407,938 & 0,86 & 144706 & & 163362,624 \\
\hline 2008 & 2377,508 & 1,28 & 178838,608 & 96,53 & 3994,082 & 2,16 & 52080 & & 185262,278 \\
\hline 2009 & 175,560 & 0,10 & 171285,323 & 98,57 & 2185,415 & 1,26 & 100320 & 21285 & 173767,903 \\
\hline 2010 & 2936,521 & 1,44 & 197828,701 & 97,28 & 3014,237 & 1,25 & & 48000 & 203355,822 \\
\hline 2011 & 5783,540 & & 173219,958 & & 3014,237 & & 25080 & 84577 & 182127,312 \\
\hline 2012 & 727,320 & & 196380,485 & & 8120,209 & & 99940 & 361346 & 205689,300 \\
\hline
\end{tabular}

Source: ONCC, 2015. Note: GF = Good Fermented; FF = Fair Fermented; FAO norms: GI = Grade I; GII = Grade II; HS = Hors Standard.

Table.7: Other crops cultivated in that district

\begin{tabular}{llll}
\hline Years/ crops & $\mathbf{2 0 0 9}$ & $\mathbf{2 0 1 0}$ & $\mathbf{2 0 1 1}$ \\
\hline Bananas & 104282 & 228803 & 268330 \\
Cocoa beans & 101875 & 101827 & 99901 \\
Coffee & 9548 & 12564 & 8563 \\
Rubber & 52497 & 50215 & 50983 \\
oil Palm & 89560 & 99562 & 100758 \\
Peanut & 32413 & 5981 & 37601 \\
pineapple & 1968 & 2069 & 2098 \\
Plantain & 130636 & 153977 & 293375 \\
Maize & 156747 & 172740 & 154948 \\
Rice & 1407 & 1947 & 1874 \\
\hline
\end{tabular}

Source: INS, 2015 
Appendix

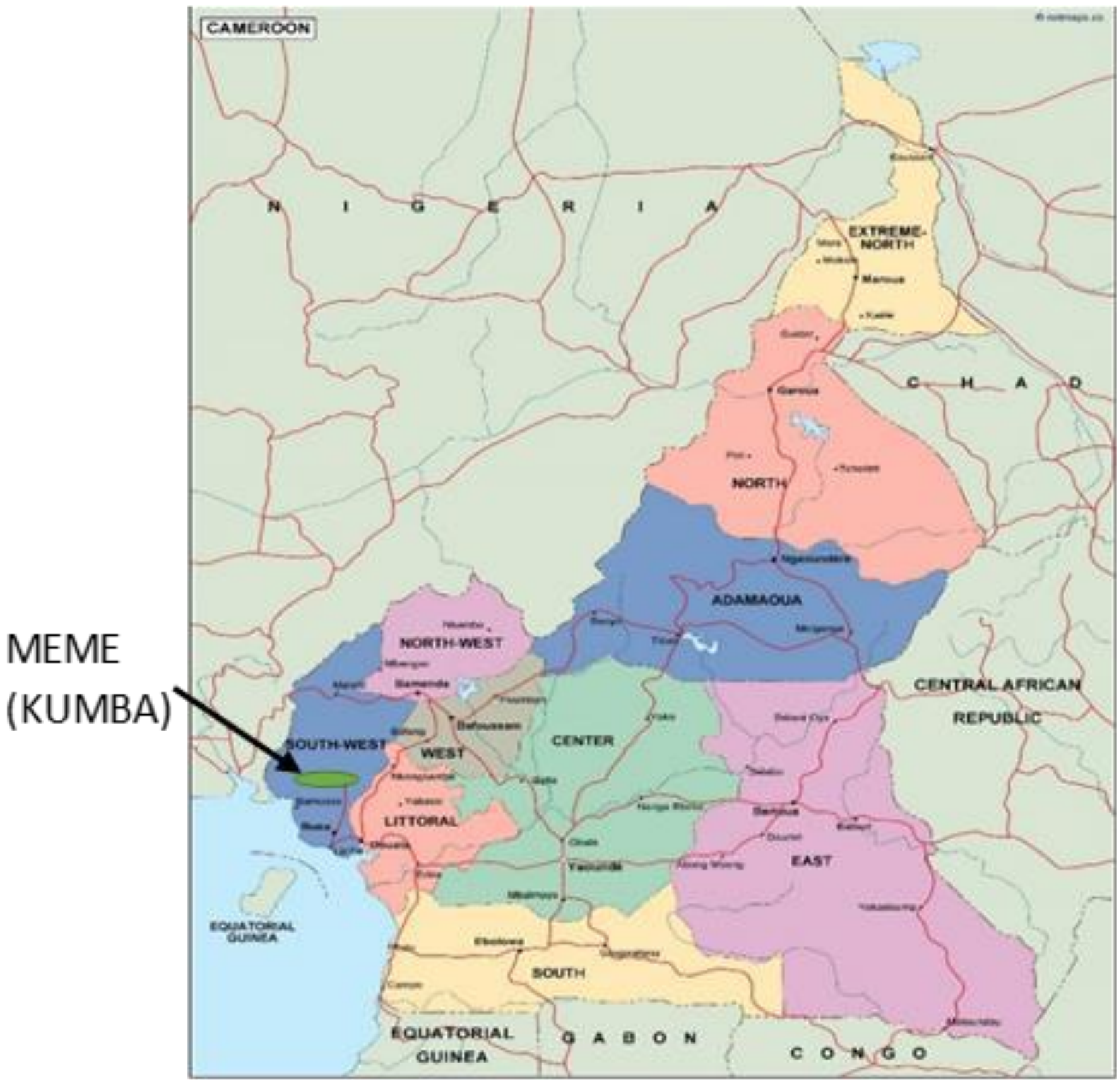

Fig.1: Survey location. Source: INS 2008 


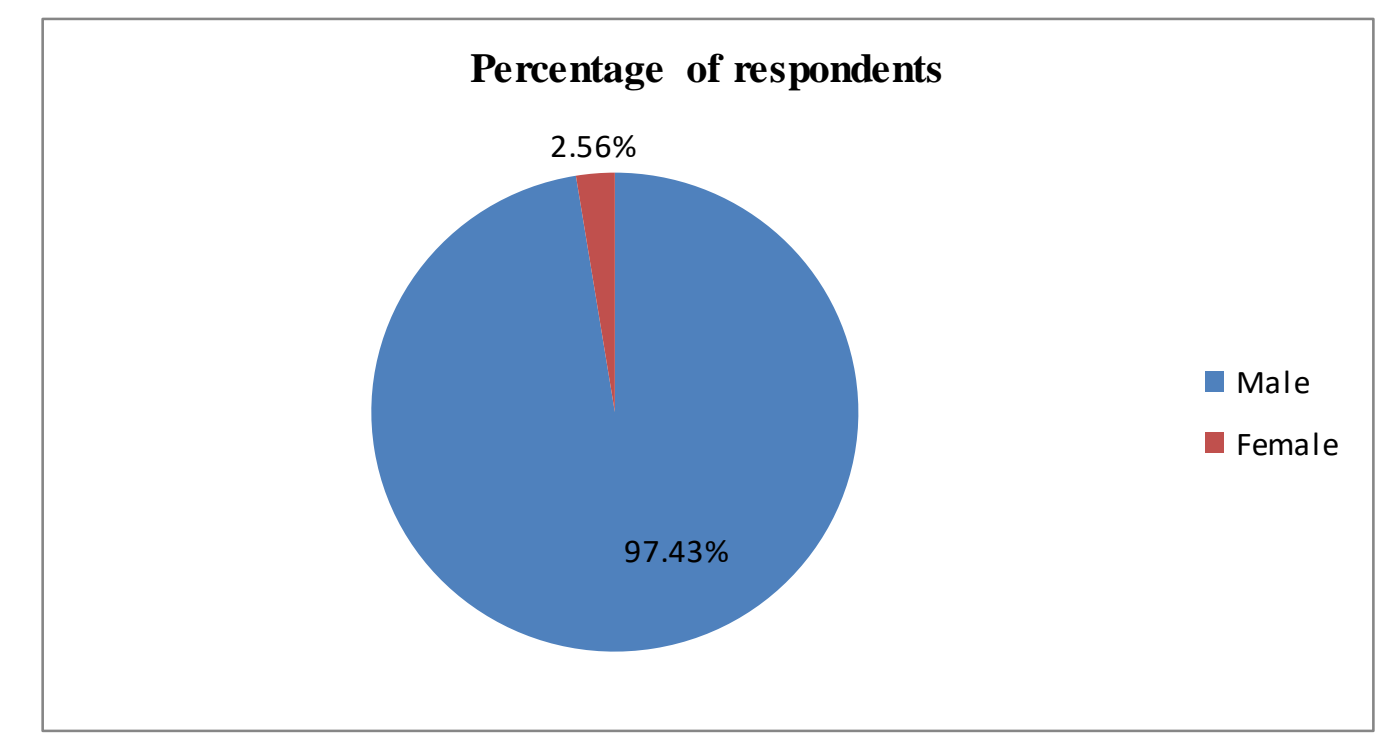

Fig.2; Percentage of respondents by gender

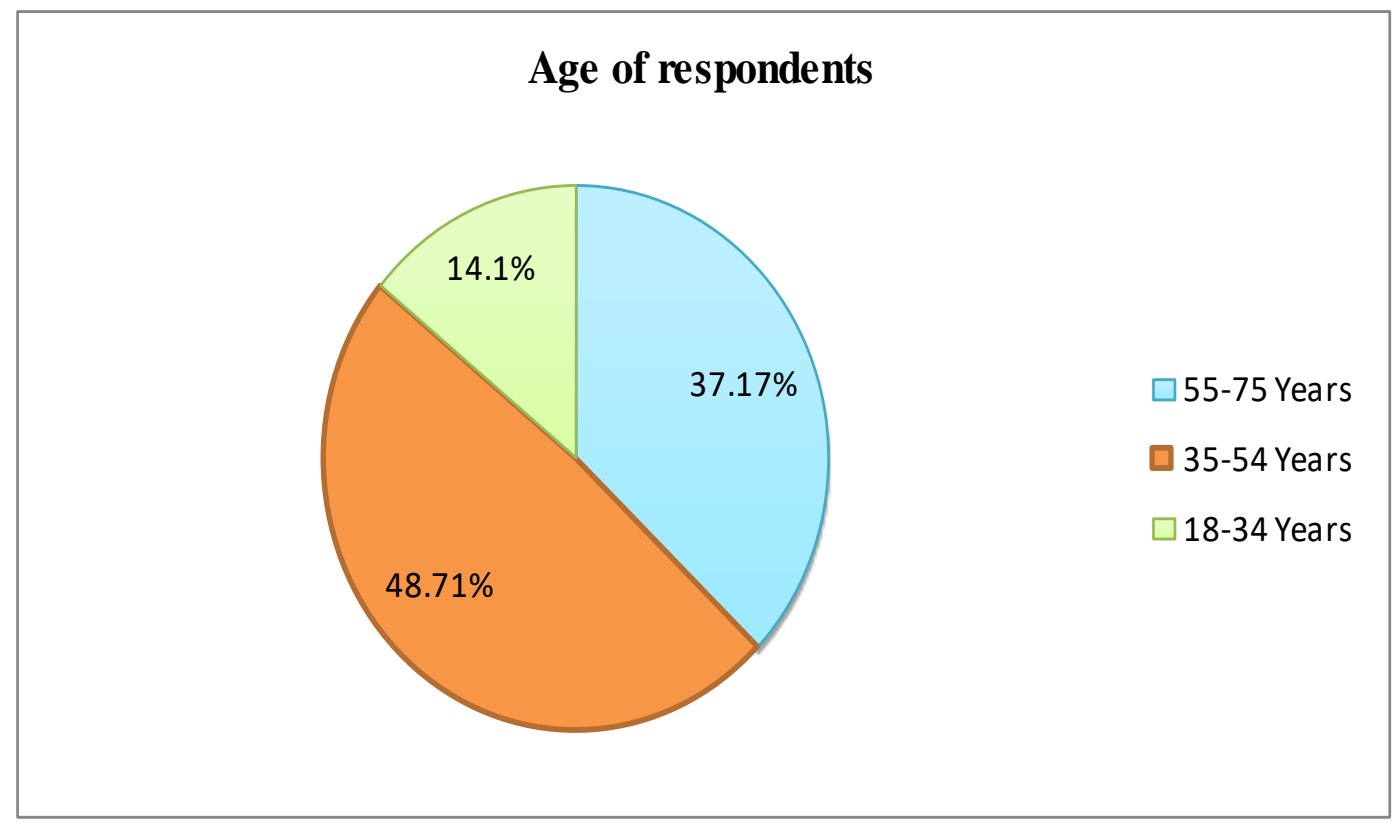

Fig.3; Percentage age of respondents 


\section{Education level of respondents}

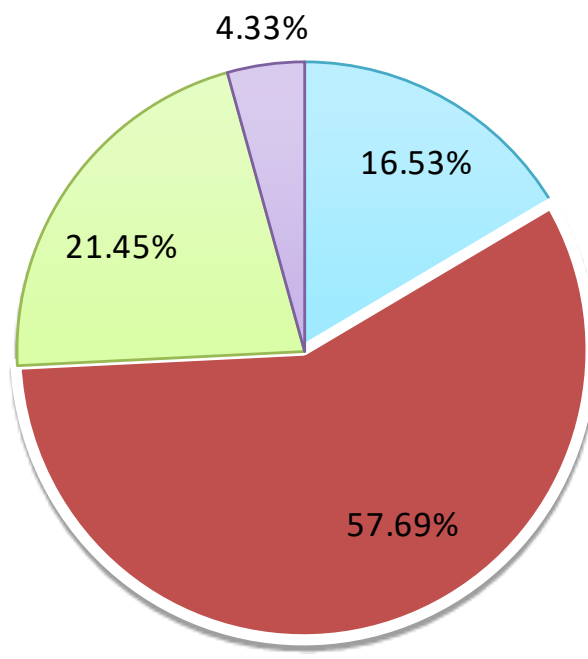

$\square$ Informal

- Basic/junior

$\square$ Senior high

$\square$ Tertiary

Fig.4; Percentage of respondents by education level

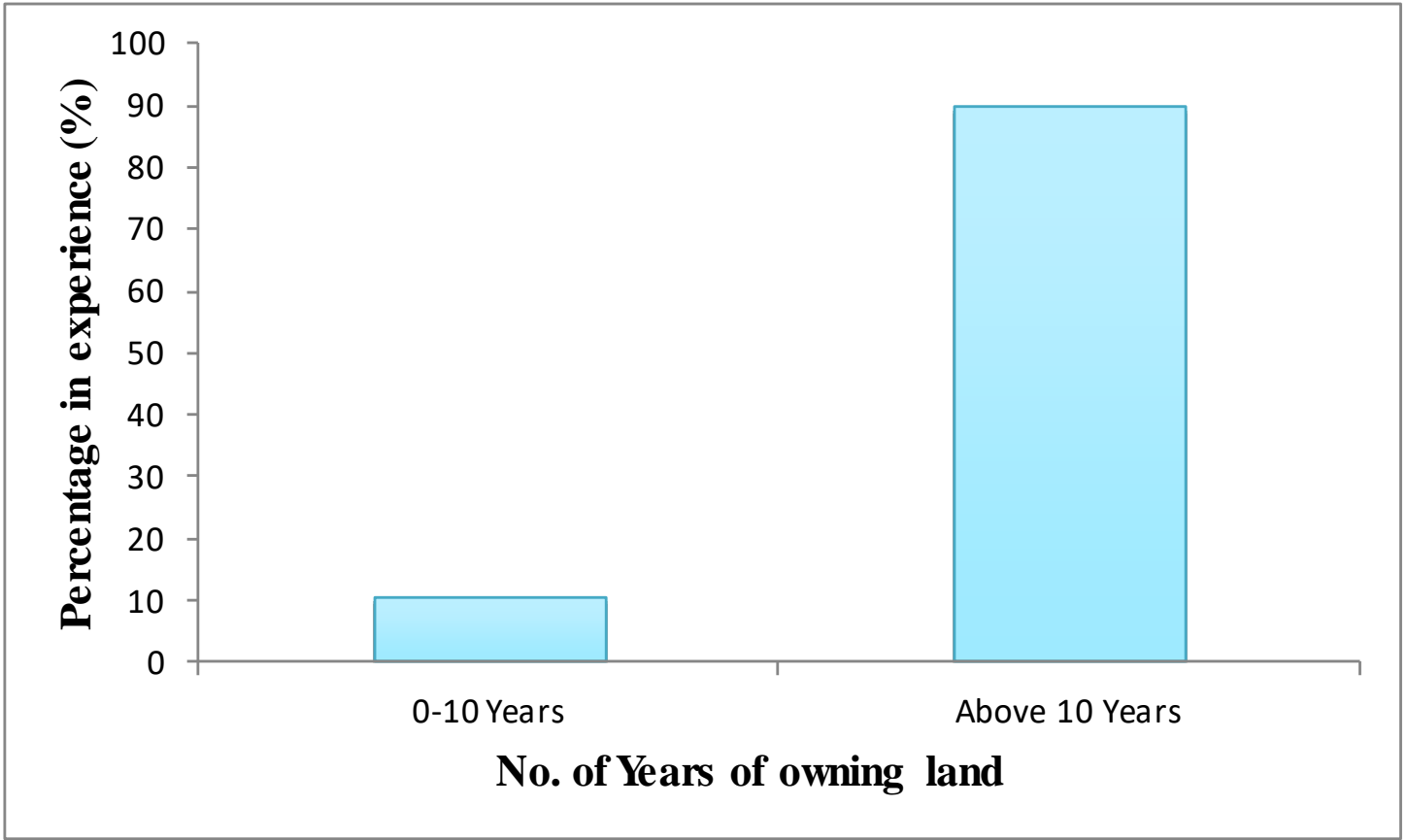

Fig.5; Percentage of land ownership by average age 